\title{
The Gendered and Heterosexist Evolution of the Teacher Exemplar in the United States: Equity Implications for LGBTQ and Gender Nonconforming Teachers
}

\author{
Michele Kahn \\ University of Houston-Clear Lake \\ U. S. A. \\ Paul C. Gorski \\ George Mason University \\ U. S. A.
}

ABSTRACT: Challenges confront lesbian, gay, bisexual, queer, and transgender public school teachers or those who are perceived as such or who desire to be open about their sexual orientations or gender identities or expression. Teachers who do not conform to gender and sexual orientation norms currently are and historically have been the subject of persecution, urban myths, and general hysteria-part of bigger efforts to normalize heterosexuality and cisgender-ness through the development of a distinctive "exemplar" related to who teachers should be. We examine the related historical and legal context of gender and sexuality in schools and then offer suggestions regarding how to redress the lingering impacts of gender- and heteronormativity.

KEYWORDS: teachers, gender, sexual orientation, heterosexism, LGBT

A Gender-norming and Hetero-norming History of U. S. Teachers Case Law and Legislation on Gender- and Heteronormative Exemplar Dismantling the Notion of Exemplar

Conclusion

Note

References

Appendix A-Selected LGBT Cases and Incidents

Author Contact

Teachers in the United States historically have been held to a higher expectation of conforming to social norms than the average citizen (DeMitchell, Eckes, \& Fossey, 2009; Grumet, 1988; Hoffman, 2003). Whether it is a behavior, appearance, or orientation, any deviation from the accepted norm has often been met with negative consequences ranging from verbal reprimands to loss of employment. In legal terms this expectation of conformity is known as exemplar and has been used to justify many 
disciplinary actions against and dismissals of lesbian, gay, bisexual, transgender, and queer-identifying (LGBTQ) teachers (DeMitchell et al., 2009).

For example, in a 1969 case in California, Mr. Morrison, a secondary high school teacher, was fired when a fellow teacher revealed to the superintendent that Mr. Morrison had engaged in same-sex intimate behavior. Mr. Morrison's teaching qualifications were revoked based on "moral unfitness" (Morrison, 1969). Nearly 30 years later, in 1997, a group of parents in Utah lobbied to have the teaching license of a teacher named Ms. Weaver revoked. Ms. Weaver was a psychology teacher and award-winning volleyball coach, but the parents claimed that she was breaking sodomy laws and that as an "out" lesbian teacher she could not be a positive role model (Florio, 1997). These and other cases are products of an implicit adherence to a prototype of the exemplar teacher molded through the feminization of teaching and the patriarchal and heterosexist ideology in which it is entrapped.

In this essay we explore the history, evolution, and consequences of this prototype and how it has been used to perpetuate sexism and heterosexism in the United States, paying particular attention to its impact on LGBTQ teachers. We recognize that, although an emergent body of scholarship addresses the experiences of LGBTQ teachers (see, for example, DeJean, 2004; Gorski, Davis, \& Reiter, 2013), most scholarship on homophobia and heterosexism in educational contexts focuses on the student experience. Additionally, heterosexism and gender oppression leveled against teachers and codified, whether explicitly into school policy or more implicitly into school culture, have an impact that extends beyond teachers to nonconforming students. It is, in essence, an additional layer of heteronormativity, or the normalization of heterosexuality and the demonization of any other sexual orientation or identity.

We begin by providing a "gendered" history of teaching, as this is the foundation from which the feminized, heteronormative prototypical notion of "teacher" emerged. We turn, then, to a review of feminized, heteronormative exemplar case law and its impact on LGBTQ teachers. In doing so we address effects on teachers as well as more general school climate concerns that affect both LGBTQ teachers and LGBTQ students because broader school policy and practice, even if it does not explicitly target teachers, can send a message about how the institution does or does not value certain people. We conclude by sharing some of the ways in which these oppressive conditions can be removed from schools.

As we examine the history and current application of the exemplar, we note that the creation and application of the exemplar, like the evolution of any sort of identity normalization, is not a linear and explicit process. The analysis of a prototype of exemplar is not a process of connecting one instance to another in a linear fashion, but a process of examining patterns and conditions through history. We do not present any one example below as, by itself, evidence of the exemplar and its effects. Rather, we present the pattern and sum of conditions we describe as the intermingling of the evolution of the exemplar standard and its effects on LGBTQ teachers.

We note, as well, that gender-normativity and heteronormativity often are policed through some of the same or overlapping norming mechanisms (Lugg, 2003; Shields, 2008), making either difficult to discuss with appreciable sophistication without 
considering the other. In this spirit we discuss them as overlapping forces informing a gendered and heteronormative construction of the teacher exemplar. Still, because they are unique components of identity around which revolve unique, even if interlocking, forms of oppression, we recognize the importance of explaining how we use each term.

\section{A Gender-norming and Hetero-norming History of U. S. Teachers}

Most professions are gendered to at least some degree. Job descriptions often are subtly or even intimately associated with gender expectations. However, few professions are as gendered and as publicly scrutinized in the United States as teaching.

The prototype teacher is a heterosexual woman. In fact, in $201276 \%$ of teachers were women (U.S. Department of Education, 2015). This might make it difficult to imagine that, at one point in the Puritan history of the colonized United States, teaching was considered the domain of men. For example, although the type of schooling in the colonies varied due to the concentration of different religious groups, class differences, and common countries of origin, gender segregated and differentiated education was common everywhere. The proportion of male teachers varied according to region during the country's colonial period, but everywhere among settler colonialists formal teaching was dominated by men. In New England, for instance, it was considered the father's duty to teach his children how to read and write (Mintz, 2004). According to Mintz, in Massachusetts, the General Court ordered that fathers provide spiritual training to their children. Many of the childrearing manuals during this time were geared toward men rather than women. By the end of the $17^{\text {th }}$ century, a few noncompulsory schools had been formalized, thanks to the Famous Old Deluder Satan Act of 1647, which required the establishment of grammar schools for boys in towns with 100 or more families.

Girls received little formal education in the colonized United States during the $17^{\text {th }}$ and $18^{\text {th }}$ centuries (Woody, 1929). Some attended "dame schools"-informal educational arrangements often carried out by women in private homes. If a family was wealthy enough, it might employ a governess to teach young women sewing, drawing, and languages. The lack of widespread education for women naturally contributed to the lack of female teachers. Then, by the turn of the $19^{\text {th }}$ century, the industrial revolution and growing immigrant populations began to transform the country. White women joined the ranks of teaching in increasing numbers as White men found more lucrative opportunities in the burgeoning factories (Sugg, 1978).

The Common School movement gained momentum in the 1830s as reformers argued for greater governmental influence on schooling. The movement was based on the notion that children-in most contexts, solely White children-in the United States should be educated toward common "beliefs, aspirations, and values" (Gutek, 1995, p. 456). Horace Mann, a lawyer and legislator, became the first US Secretary of Education in 1837. He championed women's entry into the teaching profession (Urban \& Wagoner, 2014). 
As schools became more standardized, so began the institutionalization of gender role expectations in schools. Schools became centralized, modeled after the factories that were flourishing during the industrial revolution. The goal was to educate as many children as possible with the least possible amount of teacher preparation and state funding. Moreover, the population boom of the $19^{\text {th }}$ century, driven largely by growing numbers of immigrants, increased policymakers' and religious leaders' sense of urgency to equip schools with teachers who could inculcate "American" Protestant morality (Tyack, 1974).

Mann (1841), along with other prominent figures like Catherine Beecher, lobbied in support of women teachers, arguing that they had purer morals, were natural teachers and nurturers, and were endowed with a sort of missionary zeal: in other words, that they were perfectly suited for teaching. Women who were hired as teachers were paid as little as one-third the salary of male teachers, also making them more affordable (Beecher, 1846; Clifford, 2014; Hoffman, 2003; Richardson \& Hatcher, 1983). The popularization of White women's entry into teaching coincided, as well, with the height of what came to be known as the cult of domesticity and true womanhood, a sort of White middle and upper class ideology built on very clear gender roles:

- Men worked outside of the home, in the public sphere, and were responsible for providing for the family financially. The outside world was full of dangers and temptations, and women, as the weaker sex, were to be protected from these dangers and temptations.

- Women's domain was the home, the private sphere. They were in charge of cooking, cleaning, and mothering. Their opportunities to become teachers grew as people began to see schools as extensions of home-part of the private, rather than public sphere.

- Women were expected to follow the four pillars of true womanhood: piety (or religious zealousness), purity (particularly in a sexual sense), domesticity, and submissiveness (or obedience to men) (Strober \& Gordon,1986; Sugg, 1978; Welter, 1966).

Beginning in the 1820s, following the industrial revolution, this ideal womanhood interacted with, reciprocally shaped, and reinforced notions of masculinity and forces of patriarchy that permeated all aspects of life, including vocational aspects and, as a result, teaching (Hoffman, 2003; Richardson \& Hatcher, 1983). Blount (1996, 1998, 2004, 2006), whose scholarship documents how schools have attempted to police gender and sexual identity, explains how, as teaching shifted from being men's domain to being women's domain, men shifted their attention to seeking out more masculinized-powerful, prestigious, profitable-domains such as school administration, further cementing the hegemonic gender roles that remain in place in the U. S. school system today. More specifically, these positions were accessible to White men, not men of color. Moreover, the development of school, state, and federal legislation served to maintain the missionary, pure ideal upon which women's entry into teaching was sanctioned, and a close vigilance of traditional gender roles where women's and men's appearance and behavior were expected to reflect their biological sex (i.e., if one is born female, one must look and behave in feminine ways and be 
attracted to men). Any deviation, such as same-sex attraction, whether real or perceived, or non-normative gendered appearance was punished (see Appendix A).

Another gendered dynamic that became more popular during the late $19^{\text {th }}$ century and that contributed in explicit and implicit ways to the teacher exemplar was the trend of White schools hiring only single women as teachers. Some administrators were concerned that women would have mixed loyalties if they were married. Eventually, particularly in urban areas, housing arrangements were created to accommodate the growing numbers of single women who were teachers (Blount, 2000). Many women who were teachers shared living arrangements.

Then, during the late $19^{\text {th }}$ and early $20^{\text {th }}$ centuries, researchers began to associate "spinsterhood" with lesbianism, leading to what Blount (1996) called the lesbian threat. The scientific community of the time was producing texts that raised concerns about the "unnatural" conditions and the health risks associated with the "deviance" of women cohabitating. These associations of singlehood and lesbianism were further induced by Davis's 1929 study of married and unmarried women's sexual experiences. Davis found that at least half of single women who were educators had experienced intense emotional relationships with other women. This study, coupled with the mental hygiene movement, which was concerned with the negative consequences that "spinsterhood" would have on women-supposed symptoms included crabbiness, nervous breakdowns, and bitterness-began to dismantle the preference for single teachers (Blount, 2000). By the time the post-World War II teacher shortages increased demand for teachers, marriage bans were eliminated, but firmly in place were perceived needs and justifications for policing the sexualities and gender identities of teachers.

Men who did not confirm their gender identities, or at least the way they presented in terms of gender, then, like today, were assumed by many people to be gay. According to psychologist G. Stanley Hall (1908), "proper" masculine men would become feminized working alongside so many women. Waller (1932) contributed to this belief, too, stating that within the group of unmarried teachers who have not fulfilled their "biological destiny in marriage," there remains a large group "whose sex life is thwarted or perverse" and "often consciously and usually with the best of intentions, carry sex problems into the schools, and transmit abnormal attitudes to their pupils" (p. 143). "Proper" (hegemonic) gender role behavior, following dominant gendered norms, thus became paramount to teachers' abilities to secure and maintain employment and to avoid the hostilities of heteronormativity and heterosexism.

Around the same time, the publication of Sexual Behavior in the Human Male (Kinsey, Pomeroy, \& Martin, 1948) helped to cement the notion of the homosexual menace. In their study, Kinsey and his colleagues revealed that at least half of the men they interviewed about their sexual behavior admitted to being attracted to some degree to other men. Although Kinsey's study on male sexual behavior and the follow-up study on female sexual behavior made sexuality more visible in public discourse, it also helped spur the panic surrounding homosexuality in the 1940s and 1950s. Eskridge (1997) referred to this era as the apartheid of the closet. He explained:

The closet took form as a response to three legal conundrums in the 1940s and 1950s: the increasing use of sexual orientation as an important regulatory 
category, which contributed to an obsessional discourse about minority sexual orientation; the insistence of legal republicans to command state apparatus to hunt down and destroy deviant minorities, especially homosexuals, countered by the insistence of legal libertarians that homosexuals should be left alone; and the conflicting desires of homosexuals to hide behind traditional libertarian barricades while at the same time becoming more inclined to make their presence known in republican public culture. (p. 706)

These "conundrums" reflected the rigid expectations for men and women in the education milieu and further polarized their gendered positionalities. In Florida during this time, for example, a special legislative committee mandated a purging of gay and lesbian teachers, resulting in over 60 firings (Graves, 2007; Harbeck, 1992). According to Blount (2006), these conditions created pressure for many individuals in atypical gender role positions, such as women who occupied administrative roles in schools, to carefully accentuate stereotypical gender traits in order to avoid discrimination.

During the 1960s and beyond, legislation and social movements further complicated the gender identity and sexual identity expectations of teachers. The Stonewall Riots in 1969, wherein gay men responded to constant police harassment at the Stonewall Inn bar in the Greenwich Village neighborhood of New York City, represents the most well-known landmark moment for the LGBTQ rights movement in the United States. This and other forms of civil disobedience spurred the development of several LGBTQ rights organizations across the country (Carter, 2004), contributing to the incremental progress toward LGBTQ justice that continues today.

The visibility of LGBTQ concerns increased in positive ways in some schools due to the work of activists and of organizations like the Gay, Lesbian, and Straight Education Network (GLSEN), which was formed in 1990 to raise awareness about and to alleviate homophobia and heterosexism in schools. Other influential organizations include Lambda Legal, established in 1973, and the Human Rights Campaign, founded in 1980. These organizations, among many others, have advanced LGBTQ rights in and out of educational contexts. Many LGBTQ educators and gender nonconforming educators, however, continue to be implicitly or explicitly forced into the closet, and when educators are "out," they often are at risk of considerable levels of discrimination (DeJean, 2004; Paparo \& Sweet, 2014). Indeed, the standards for femininity and masculinity within a feminized profession such as teaching seem even more rigidly dichotomized as evident in the policing of sexuality, which is often monitored for compliance in gender normative appearance. Women must be "seen" as women and must be attracted to men. As seen through case law, further explored in the next section, educators who deviate from traditional masculine and feminine norms are punished.

Through the complex conditions of this sociohistory, traditional gender identity and sexual identity expectations were constructed in schools rooted in a White colonial history in ways that, despite receiving incrementally more attention in some communities, have fomented school environments conducive to the normalization of cisgenderness (when gender identity aligns, in the stereotypical sense, with biological sex) and heterosexuality and the association of other gender identities and sexual identities among teachers as deviant. They have generated the schoolmarm prototype 
along with the ascribed characteristics of Protestant purity and morality associated hegemonically with cisgenderness and heterosexuality. These conditions have been enforced socially, culturally, and politically in a wide variety of ways, from hostile working environments (Rudoe, 2010) to the silencing of concerns about heterosexism even in conversations about diversity (Clark, 2010). But they also have been enforced by the legal notion of exemplar.

\section{Case Law and Legislation on Gender- and Heteronormative Exemplar}

In order to understand how LGBTQ public school teachers are imagined in the law, it is helpful to examine the contexts within which they are viewed. Teachers are citizens operating in a space that is connected directly and intimately with the community through the students they teach. As citizens, they retain their rights, but in a limited way, constrained by the fact that they work in a public sphere and that they work predominantly with minors. Public school teachers are public employees as well as private citizens; when they cross the threshold of the school, their rights are diminished even as expectations of them expand. Teachers are expected to abide by community mores and are punished when they do not do so. Community expectations for teachers transcend teaching qualifications.

U. S. legislation related to gender identity and sexual orientation is a patchwork of contradictory laws, including progressive pockets of acceptance and rights and deep wells of Victorian prudishness and repression. Only 14 states and DC have nondiscrimination policies in their school systems, and only 19 states and DC have antibullying laws. In 36 states, educators can be fired for being or appearing LGBTQ, and in 31 states LGBTQ teachers (as well as LGBTQ students) have little or no recourse for protection against heterosexist or gendered bullying (Human Rights Campaign, 2015). Schools have notoriously ignored heterosexist and genderist bullying even when they had broad bullying policies, a situation that has contributed to suicides by LGBTQ and gender nonconforming youth. In September 2010 alone, nine youth committed suicide because of homophobic or transphobic bullying: Tyler Clementi, age 18; Billy Lucas, 15; Harrison Chase Brown, 15; Cody J. Barker, 17; Seth Walsh, 13; Felix Sacco, 17; Asher Brown, 13; Caleb Nolt, 14; and Raymond Chase, 19 (Nash, 2010). Although there is no specific record of large numbers of suicides among LGBTQ teachers, the lack of responsiveness to these issues at the institutional, state, or federal level sends a message about their worth.

In some cases, antibullying programs have been dissolved by administrators and school boards because they explicitly addressed sexual identity and gender identity (Waas \& Roland, 2012), leaving LGBTQ teachers and students vulnerable. For example, former Governor Mitt Romney attempted to halt the distribution of a Massachusetts publication, Guide to Bullying Prevention, because it contained the words bisexual and transgender in passages about harassment. It was ultimately published in 2008 when Romney was no longer governor. Other states, such as Illinois (McDermott, 2012), have ended antibullying programs because they mentioned LGBTQ issues. Conservative organizations such as the American Family Association, Mission 
America, Focus on the Family, and Americans for Truth about Homosexuality commonly fear-monger by attempting to create the perception that antibullying programs that address harassment and bias related to gender and sexual identity and schools that support Gay-Straight Alliances or other initiatives to address genderism and heterosexism are promoting a "gay agenda" (People for the American Way, 2012), harkening back to the "lesbian threat" discussed earlier and helping to cement heteronormativity.

Despite the fact that on June 26, 2015, the U. S. Supreme Court legalized same sex marriages, legal hurdles remain. LGBTQ teachers and LGBTQ citizens more generally do not have protection under federal law. States offer varying degrees of discrimination protection (Human Rights Campaign, 2015). As recently as April 2015, 35 states plus DC uphold same sex marriage, yet only 18 states and DC currently prohibit employment and housing discrimination based on sexual orientation and gender identity. In some states, like Texas, same sex couples could not get married and there was a constitutional amendment that restricted marriage to one man and one woman. Texas does not offer LGBTQ anti-discrimination employment, housing, anti-bullying or school laws. However, other states are gradually moving toward more equitable policies. Kansas, for example, supports same sex parent adoptions (but not second or stepparent adoption for same-sex couples) and has laws that facilitate gender changes on birth certificates and driver's licenses, but does not have state policy addressing discrimination related to sexual orientation and gender identity in or out of schools. Similarly, like many other states, Idaho does not have LGBTQ anti-discrimination laws in place with regard to housing, employment, hate crimes, or bullying, but does support adoption and marriage for same-sex couples (Human Rights Campaign, 2015).

At the national level, there has been a more visible push to pass the Employment NonDiscrimination Act (ENDA), which would protect LGBTQ people, including teachers, from employment discrimination. Supporters have been trying to pass this bill in nearly every Congress since 1994. ENDA finally passed the Senate in 2013 but has yet to come to a vote in the House of Representatives.

On a more positive note, the legal landscape is slowly changing. On June 12, 2012, the Equal Employment Opportunities Commission (EEOC) ruled that transgender employees are covered under Title VII of the Civil Rights Act of 1964. Title VII is a federal law that prohibits discrimination in employment on the basis of sex, race, color, national origin, and religion. In addition, the U.S. Education Department's Office for Civil Rights announced in 2014 that the 1972 Title IX civil rights law nondiscrimination clause would extend to discrimination claims based on gender identity or gender nonconforming individuals. These rulings could prove to have a significant impact on issues that affect transgender employees, including teachers, such as dress codes, bathroom access, and the legal (as opposed to social or cultural) ability to openly transition.

However, actual change often is slow to follow legal rulings in the United States. As laws protecting LGBTQ people are relatively new, there is a scarcity of scholarship on how well they are being followed or enforced. Nevertheless, considering other forms of oppression provides insight on the phenomenon of slow adjustments to legal rulings. For example, 10 years after national mandates were enacted to racially desegregate 
schools (Brown v. Board of Education, 1954), less than $3 \%$ of African American children in the U. S. South attended integrated schools. Twenty years later, just over half of African American children were in integrated schools, a reminder that laws alone will not change sociopolitical conditions (Orfield, 2005). Moreover, when LGBTQ identities intersect with other less privileged identities, such as being a person of color (Bowleg, 2013; de Vries, 2015; Singh, 2013), non-Christian (Kugle, 2013), refugee or immigrant or disabled (Alessi, Kahn, \& Chatterji, 2016), multiple layers of discrimination further complicate and stagnate change.

Ironically, while no enumerated federal laws exist to protect LGBTQ individuals in general or teachers specifically, in 1998 President Clinton signed Executive Order 13087, which prohibits discrimination on the basis of sexual orientation in the Federal civilian workforce. Although the federal government will not mandate employment protections for the general LGBTQ population, it has chosen to protect its own employees.

Even in school districts or states where LGBTQ teachers have employment protections, there is no assurance that they will not be dismissed for heterosexist or sexist reasons, often under the guise of other concerns. In 2013, the Gresham-Barlow school board in Oregon refused to renew Principal Tom Klansnic's contract. Klansnic claimed that this decision was made because he was gay, stating (as cited in Knapp, 2013), "It was very interesting to me that it happened exactly when I got divorced and exactly when I came out and told my friends and began to tell my family that I was gay. And told my wife and my son" (\$3). The district did not comment on the reasons for dismissal but settled out of court after Klansnic pursued damages. Laura Jane Klug, a transgender substitute teacher in southeast Texas, was removed from the classroom in 2014 following complaints from parents. Among the concerns were that she was "obscene," that students might ask inappropriate questions, and preoccupations as to where she might go to the bathroom. The school reassigned Ms. Klug to other duties outside of the classroom. Another case in Minneapolis involved teacher Carla Cruzan, who argued that the school violated her religious freedom and created a hostile work environment based on sex discrimination when it allowed Debra Davis, a librarian identifying as transgender, to use the women's bathroom. Although the court ruled against Cruzan, this is illustrative of the indignities that transgender employees continue to endure from the ignorance and discrimination of colleagues and parents (Cruzan v. Minneapolis Public School System, 2001).

When LGBTQ teachers are fired for their sexual orientation or gender identity, it often is disguised with language like immoral conduct or moral turpitude, with administrators or school boards interpreting what these terms mean and how they are operationalized in employment practices (DeMitchell et al., 2009), thus contributing to the maintenance of the gender- and sexual-identity-conforming exemplar. This is not unlike provisions in school codes pertaining to student clubs, as administrators may reserve the right to abolish a club if it causes a "disruption" in the school. These are subjective decisions, informed by combinations of prevailing gender and sexual identity norms, structural oppression, and desires on the parts of some schools and districts to avoid controversy. The aforementioned cases involving Mr. Morrison and Ms. Weaver exemplified these sorts of dismissals and how heterosexism, sexism, and transphobia 
drive the way that the notion of exemplar is used to solidify these oppressions in the legal system. Students are also affected by these decisions since the decisions send clear messages about how schools perceive LGBTQ people. If their teachers are punished for violating prevailing gender and sexual identity norms, students can easily draw the conclusion that groups of individuals falling outside of the norms are not worthy of being treated equitably in school and society.

Teachers who implicitly or explicitly have been fired for being LGBTQ and who have had no protections in their school contracts or under state law have relied primarily on two clauses of the amendments of the U.S. Constitution to argue their cases. The first of these is the Equal Protection Clause of the Fourteenth Amendment, which states that "no state shall make or enforce any law which shall abridge the privileges or immunities of citizens of the United States; nor shall any state deprive any person of life, liberty, or property, without due process of law; nor deny to any person within its jurisdiction the equal protection of the laws." The second is the Free Speech Clause of the First Amendment, which requires that "Congress shall make no law respecting an establishment of religion, or prohibiting the free exercise thereof; or abridging the freedom of speech, or of the press; or the right of the people peaceably to assemble, and to petition the government for a redress of grievances." As illustrated in Appendix A, these arguments have helped in some, but not all, cases. To illustrate, the courts ruled for the plaintiff in Jantz v. Muci (1992), Weaver v. Nebo School District (1998), Lovell v. Comsewogue School District (2002), and Lawrence v. Texas (2003), based on the Fourteenth Amendment but in none of the other cases.

Teachers' free speech is a fuzzy area in the law. On the one hand, teachers are granted some protections against censorship with regard to curricular matters such as the right to teach the theory of evolution. On the other hand, they often are censored when teaching about LGBTQ issues. Some states have even enacted what have been called, oppressively, "No Promo Homo" laws (McGovern, 2012). Currently, Utah, Arizona, Oklahoma, Texas, Louisiana, Mississippi, Alabama, and South Dakota have these laws in place. For example, Arizona's law states that "No district shall include in its course of study instruction which: 1. Promotes a homosexual life-style. 2. Portrays homosexuality as a positive alternative life-style. 3. Suggests that some methods of sex are safe methods of homosexual sex" (Arizona State Legislature, n.d.). Even in the states that have no explicit laws censoring discussion or inclusion of LGBTQ or gender identity issues, educators and students still contend with censorship as schools are reluctant to address what they deem to be controversial topics. In many cases these conditions permeate the entire school culture, affecting not just teachers' abilities to express their identities openly, but also the curriculum, extracurricular offerings, and student voice.

Recently, for example, an 11-year-old girl in Florida was told by her middle school teacher that she could not give a speech on gay rights. Her teacher told her she needed to pick a new topic because her topic might offend classmates and suggested she address gender or racial equality instead. After her parents took the issue to the school district, they reversed the decision (Lambert, 2015). Although it might appear as though this experience only targeted LGBTQ students, it also can be seen as a symptom of a larger culture that devalues all LGBTQ members of a school community 
and that polices the identity expression of students and educators alike.

California is the only state whose Education Code includes an LGBTQ curriculum. Following the passage of SB 48, the Fair, Accurate, Inclusive, and Respectful Education (FAIR) Act in 2011 (placed into effect in 2012), schools are required to include in their social science courses "the role and contributions of...lesbian, gay, bisexual, and transgender Americans...to the economic, political, and social development of California and the United States of America, with particular emphasis on portraying the role of these groups in contemporary society" (SB 48, \ 1). We were unable to find studies on the effect of the FAIR Act on attitudes and school climate, but previous studies have indicated that where LGBTQ issues are included or discussed in schools, LGBTQ students report feeling safer (Russell, Kostroski, McGuire, Laub, \& Manke, 2006). LGBTQ students also report feeling safer when they have Gay Straight Alliances at school (Kosciw, Greytak, Palmer, \& Boesen, 2014) and LGBT inclusive policies (Kull, Kosciw, \& Greytak, 2015). Although we have not seen research making this claim specifically, it could be that institutional support for strong curricula and other sanctioned activities and policies related to sexual orientation and gender identity help to create cultural conditions, or perhaps reflect existing cultural conditions, that would make it easier for nonconforming teachers to reject the pressure of conforming to the exemplar, at least to some degree.

Of course, when it comes to matters of equity, institutional culture is shaped not only by the ways in which marginalized people are treated, but also by the way the people doing the marginalizing are treated. Jerry Buell, a history teacher in Florida, announced on Facebook after same sex marriage was legalized in New York:

I almost threw up ... Now they showed two guys kissing. If they want to call it a union, go ahead. But don't insult a man and woman's marriage by throwing it in the same cesspool... God will not be mocked. When did this sin become acceptable? (as cited in Padgett, 2011, \ 2)

Although the school district removed him at first, it had to reinstate him later because, the district contended, his speech was protected (Padgett, 2011). Free speech is protected when acting as a private citizen under the First Amendment, such as the 1968 landmark case when Illinois high school teacher Mr. Pickering was dismissed when he wrote a letter to a newspaper criticizing the Board of Education funding actions. Pickering (1968) sued, claiming his First Amendment rights were violated, and won. The court reasoned that while teachers are public employees (thus representing the school) they are also private citizens and retain first amendment rights. However, whether or not LGBTQ or gender nonconforming teachers "come out," in or out of the school environment, they are susceptible to repercussions (Bower \& Klecka, 2009; Rudoe, 2010). Heterosexual and cisgender teachers do not face this dilemma unless they are assumed to be LGBTQ or otherwise nonconforming, a condition that, once again, solidifies the establishment of exemplar.

Most LGBTQ and gender nonconforming teachers are still working in what Eskridge (1997) called the "apartheid of the closet" as:

a regime in which homosexuals were segregated from civilized society, not physically, but psychically and morally. So long as they confined their 
expressions and actions to a mutually protective closet, homosexuals were promised a regime of "separate but equal" toleration from the liberals and legal protection from the witch hunters. (p. 707)

He further explains, "While the antihomosexual police officer can later be kept in check by the closet respecting judge or prosecutor, the judge or prosecutor is limited in her or his ability to stop the police officer from engaging in harassment in the first place" ( $p$. 772). Although legislation can help to keep school administrators and community policies in check, it is limited in the extent to which it can stop discrimination and harassment from happening. It is limited in its ability to reshape the heterosexist and heteronormative institutional cultures that continue to permeate all aspects of public schooling in the United States (Prettyman, 2007). So even when legal cases eventually have favored the marginalized party, it almost always has been only after years of psychological, emotional, and financial repercussions. Again, although the oppressive exemplar might be legally revoked, the pressure to conform remains.

According to DeMitchell et al. (2009), the courts' use of the concept of exemplar to prove teacher unfitness is beginning to shift. More and more courts are requiring schools to bear the burden of proving that employees' sexual orientation or gender identity or expression is impairing their abilities to teach effectively. This appears, at least potentially, to be a promising shift, putting the onus of responsibility on the institution to provide evidence beyond teachers' nonconformity that they are unfit to teach. Unfortunately, in most contexts, much of the damage is done as soon as questions are raised about a teacher's performance when those questions are linked to the teacher's gender or sexual identity. In that sense, it will be important to track how or whether these legal shifts impact the social, cultural, and institutional notion of the teacher exemplar. In the meantime, a commitment to equity requires justice-minded educators to work activity to change social, cultural, and institutional attitudes regarding gender and sexual identity.

\section{Dismantling the Notion of Exemplar: Cultivating Equitable Schools}

Dismantling the notion of exemplar and moving towards LGBTQ and gender equity for teachers involve addressing heterosexual hegemony and disrupting traditional gender models at the cultural, social, and institutional levels (Prettyman, 2007). This is a complex undertaking for a variety of reasons. For example, it is entangled with religious fundamentalism, which shapes the morality norms that continue to bleed into secular life in the United States and its public schools (Finlay \& Walther, 2003; Sapp, 2013). Additionally, at the institutional level, we must address issues like employee policies and work toward legal protections of LGBTQ and gender nonconforming teachers, but these changes will not be effective or perhaps even enforced if individual attitudes and institutional cultures remain static. Third, research has shown that, on average, teacher education programs inadequately prepare current and future educators to create equitable school environments for LGBTQ educators, students, and family members either by omitting concerns related to gender identity and sexual orientation from the curriculum altogether, including these concerns only in conversations that do not 
address institutional oppression (as in conversations about "bullying"), or actually nurturing the biases students carry into the programs with them (Gorski et al., 2013).

In this section we challenge educators, education activists, and LGBTQ and gender justice activists to work through these challenges and dedicate themselves to erasing the oppressive and hegemonic notion of exemplar along with the implications of the exemplar standard that historically have wreaked havoc on the lives of many LGBTQ and gender nonconforming teachers. Too often movements for this kind of change are based on ahistorical assumptions that schools change at the same pace as society and the sociocultural conditions of the present day (Rury, 2004), which can create undue complacency about existing conditions of educational inequity. The challenges we pose here are based on a firm understanding of present conditions and the histories behind them. They are meant as approaches for change that can be used alongside the continued legal challenges to heterosexist, sexist, and trans-oppressive policies and practices that permeate public schools and deteriorate the working conditions of teachers.

The process begins with recognizing and dismantling not only the gendernormative and heteronormative notion of teacher exemplar, but also with any attempt, however implicit, to marginalize teachers of any identity (or assumed identity) through the normalization or privileged identities and ways of being.

\section{Leadership Taking Leadership}

Too often, the onus of shifting problematic institutional culture in schools is handed down from leadership to relatively powerless diversity committees, to people who volunteer to take on diversity specialist roles beyond their teaching jobs, or even to students through diversity clubs. Although cultural change can be a bottom-up phenomenon and often requires organizing on the parts of people who do not have positional leadership power, change efforts in schools often are undermined by positional leaders who refuse to take a public stand on issues that might be seen as controversial (Wright, 2010). Educational leaders, and particularly those with positional power, must play a lead role in erasing the heteronormative and gender-normative exemplar by publicly challenging gender- and heteronormative messages, policies, and practices (Levin-Epstein, 2015). Educational leaders can take note that schools that have implemented Gay Straight Alliances, more inclusive curricula, and comprehensive bullying and harassment policies have all shown improvement towards LGBT equity (Kosciw et al., 2014; Kull et al., 2015; Russell et al., 2006). But, as the items in this list illustrate, these efforts are not, by themselves, enough.

\section{Analyzing Policy, Practice, and Tradition}

Even when LGBTQ and gender nonconforming teachers are not being fired or publicly criticized by parent collectives, they still often are targeted with explicit or 
implicit forms of bias and discrimination (DeJean, 2004; Paparo \& Sweet, 2014). The most insidious remnants of the hetero- and gender-normative exemplar, which can create consistent and grinding pressure for these teachers to conform to the exemplar standard, often are buried in subtle school policy, practice, and tradition. This is why it is not sufficient to respond only to explicit bullying or discrimination (Aiden, Martson, \& Perry, 2013; Monk, 2011). Instead, we must critically analyze the ways in which the exemplar standard is embedded in school policies, practices, and traditions.

It is important to remember when doing so that even policy and practices that are hostile to LGBTQ students help to create, by extension, the normative culture in which teachers exist and vice versa. For example, explicit teacher dress codes or implicit teacher dress expectations that are applied based on the teachers' presumed sex, rather than their gender identities or expressions, communicate sociocultural norms to all members of a school community (Sausa, 2005). It is important to remember, as well, that we cannot mitigate oppression away by, for instance, ignoring these cultural norms and putting Safe Space stickers on the office doors of teachers who are attempting to create a welcoming environment for LGBTQ and gender nonconforming students and colleagues or offering anti-bullying professional development. Erasing the damaging norms requires a serious examination of the values that underlie the culture of the institution, even if they do so only in implicit ways (DePalma \& Atkinson, 2009).

\section{Gender Inclusive and Non-heteronormative Language}

One of the most insidious ways in which gender-normativity and heteronormativity is reaffirmed is through the use of gendered and heteronormative language, in both official and casual communication (Leaper \& Bigler, 2004). All forms of communication, from Web sites and official school documents to curricula and staff memos, should use language that is gender inclusive and non-heteronormative. Are there implicit ways in which heterosexuality is normalized in these communications? Are there images that depict people in traditional gender roles? Is binary (e.g., gay/straight) language used in ways that ignore the fluidity and complexity of gender and sexual identity?

\section{Professional Development beyond Bullying}

Language is deeply socialized, and often a very clear reflection of the values in an organization. As a result, it can take a substantial amount of time to re-socialize people into different language practices and often people are resistant to changing their language. So while it is important to work on shifting language itself by challenging people to use more inclusive language, these shifts should be informed by evolutions in organizational and individual ideology. This requires professional development.

Unfortunately, professional development related to LGBTQ concerns tends to focus on interpersonal symptoms, such as bullying, rather than the ideologies that result 
in those symptoms (DePalma \& Atkinson, 2009). In order to create more equitable environments for gender nonconforming and LGBTQ teachers, professional development should focus less on bullying or simplistic approaches to cultural competence and more on equity literacy (Gorski, 2016; Gorski \& Swalwell, 2015). Equity literacy is an approach to teacher development that is designed to equip educators with the knowledge and skills they need to recognize, respond to, and redress inequities. It first cultivates the ability to recognize even the subtlest forms of bias and inequity - the ability to see the conditions educators are conditioned not to see, particularly in cases in which we are part of the dominant group. It focuses, then, on learning how to respond to bias and inequity in the immediate term. For example, how would I, as an educator, respond if I heard a colleague using gender- or heteronormative language? Finally, equity literacy is designed to equip educators with the knowledge and skills to redress bias and inequity in the long term by addressing the underlying causes, such as by helping to change the cultural dynamics of the school that made a colleague think they would be supported in their heteronormative views (Gorski \& Swalwell, 2015). Several national and international organizations offer workshops or toolkits that address both structural and interpersonal dimensions related to LGBTQ concerns, including the Gay, Lesbian, Straight, Education Network (GLSEN); the Human Rights Campaign (HRC); the European Region of the International Lesbian, Gay, Bisexual, Trans and Intersex Association (ILGA); the Gender Spectrum; and the National Center for Transgender Equality (NCTE).

\section{Queering Teacher Education Programs}

Teacher and administrator education programs have the potential to help break the cycle of apathy and ignorance regarding heterosexism and sexism in schools. They should do a better job educating future teachers and administrators on issues beyond instructional methodology, the curriculum, and school management and infuse more courses related to educational equity. However, a study of course offerings in 302 teacher education programs found that approximately $75 \%$ did not offer a multicultural education or educational equity course (Neumann, 2010). Furthermore, in their analysis of multicultural teacher education courses, Gorski and Goodman (2011) found that $41.46 \%$ included no mention at all of sexual orientation. Of course, in order to adequately prepare teachers and school leaders, teacher educators need professional development regarding sexual orientation and gender identity and expression as well.

\section{Conclusion}

The continued marginalization of LGBTQ and gender-nonconforming teachers is facilitated, in part, by social and cultural forces that define heteronormative and gendernormative expectations for all members of school communities. Although lesbian and gay individuals slowly are winning more protections in some parts of U. S. society, implicit and explicit school cultures remain, on average, hostile to teachers who do not 
conform to the gender-binary and heteronormative exemplar. Certainly in some regional contexts conditions are improving. Still, this notion of exemplar is rooted in a long history and a stubborn present of implicit and explicit school, district, state, and federal policy and practice and cannot be alleviated without pointed efforts to recognize its hold and reverse its heterosexist and gender-oppressive impact. The purpose of this essay was to detail this history and present, helping to outline part of the sociopolitical context of school inequity in order to better prepare ourselves and our colleagues committed to educational equity to address these issues with vigilance and depth.

\section{Note}

1. Guidance for language use can be found at: http://www.hrc.org/resources/glossaryof-terms.

\section{References}

Acanfora v. Board of Education of Montgomery County, 359 F. Supp. 843 (D. Md. 1973) Retrieved from http://www.joeacanfora.com

Aiden, H., Marston, K., \& Perry, T. (2013). Homophobic bullying: How well do we understand the problem? Bristol, UK: Educational Action Challenging Homophobia.

Alessi, E. J., Kahn, S., \& Chatterji, S. (2016). "The darkest times of my life'”: Recollections of child abuse among forced migrants persecuted because of their sexual orientation and gender identity. Child Abuse \& Neglect, 51, 93-105.

Arizona State Legislature (n.d.) Retrieved from http://www.azleg.state.az.us/ FormatDocument.asp?inDoc=/ars/15/00716.htm\&Title=15\&DocType=ARS

Basu, M. (2013, January 11) Transgender teacher sues Catholic prep school for alleged discrimination [Web log post]. Retrieved from http://inamerica.blogs.cnn.com/2013/01/11/transgender-teacher-sues-catholicprep-school-for-alleged-discrimination/

Beecher, C. (1846). The evils suffered by American women and American children: The causes and the remedy. New York, NY: Harper \& Row.

Blount, J. M. (1996). Manly men and womanly women: Deviance, gender role polarization and the shift in women's school employment, 1900-1976. Harvard Educational Review, 66(2), 318-339.

Blount, J. M. (1998). Destined to rule the schools: Women and the superintendency, 1873-1995. Albany, NY: State University of New York Press.

Blount, J. M. (2000) Spinsters, bachelors and other gender transgressors in school employment, 1850-1990, Review of Educational Research, 70(1), 83-101. 
Blount, J. M. (2004) Social studies and the creation of otherness: Sexuality/gender transgression, 1920-1980. In J. Watras, C. Woyshner, \& M. Crocco (Eds.), Social Studies in the twentieth century: Curriculum and context for citizenship (pp. 176191). New York, NY: Peter Lang.

Blount, J. M. (2006). Fit to teach: Same-sex desire, gender, and school work in the twentieth century. Review of Educational Research, 70(1), 83-101.

Bower, L., \& Klecka, C. (2009). (Re)considering normal: Queering social norms for parents and teachers. Teaching Education, 20(4), 357-373.

Bowers v. Hardwick 478 U.S. 186 (1986).

Bowleg, L. (2013). "Once you've blended the cake, you can't take the parts back to the main ingredients": Black gay and bisexual men's descriptions and experiences of intersectionality. Sex Roles: A Journal of Research, 68(11-12), 754-767.

Brown v. Board of Education, 347 U.S. 483 (1954).

Burton v. Cascade School Dist. Union High School No. 5, 512 F. 2d. 850 (1975).

Carter, D. (2004). Stonewall: The riots that sparked the gay revolution. New York, NY: St. Martin's Press.

Citizens of Nebo School District v. Weaver 29 F. Supp. 2d 1279 (D. Utah 1998).

Clark, C. T. (2010). Preparing LGBTQ-allies and combating homophobia in a U.S. teacher education program. Teaching and Teacher Education, 26, 704-713.

Clifford, G. J. (2014). Those good Gertrudes: A social history of women teachers in America. Baltimore, MD: Johns Hopkins University Press.

Cruzan v. Minneapolis Public School System165 F. Supp. 2d 964 (2001)

Davis, K. B. (1929). Factors in the sex life of twenty-two hundred women. New York, NY: Harper Brothers.

DeJean, W. (2004). Gay male high school teachers: A taxonomy of fear. Encounter: Education for Meaning and Social Justice, 17(3), 19-23.

DeMitchell, T., Eckes, S., \& Fossey, R. (2009). Sexual orientation and the public school teacher. Boston University Public Interest Law Journal, 19(1), 65-105.

DePalma, R., \& Atkinson, E. (2009). 'No outsiders': Moving beyond a discourse of tolerance to challenge heteronormativity in primary schools. British Educational Research Journal, 35, 837-855.

de Vries, K. M. (2015). Transgender people of color at the center: Conceptualizing a new intersectional model. Ethnicities, 15(1), 3-27.

Eskridge, W. (1997). Privacy jurisprudence \& the apartheid of the closet, 1946-1961. Florida State University Law Review, 24, 703-838

Florio, G. (1997). She's out, now parents want her ousted. Philadelphia Inquirer Online. Retrieved from http://articles.philly.com/1997-11-14/news/25545119_1_spanishfork-high-school-parents-or-other-teachers-school-board 
Finlay, B., \& Walther, C. (2003). The relation of religious affiliation, service attendance, and other factors on homophobic attitudes among university students. Review of Religious Research, 44(4), 370-393.

Gaylord v. Tacoma Sch. Dist. 85 Wn.2d 348 (1975).

Glover v. Williamsburg Local School District Board of Education California Dist., $20 \mathrm{~F}$. Supp. 2d 1160 (S.D. Ohio 1998).

Gorski, P. (2016). Equity literacy: More than celebrating diversity. Diversity in Education, 11(1), 12-15.

Gorski, P., Davis, S., \& Reiter, A. (2013). The (in)visibility of sexual orientation, heterosexism, homophobia, and other LGBT concerns in U.S. multicultural teacher education coursework. Journal of LGBT Youth, 10(3), 224-248.

Gorski, P., \& Goodman, R. (2011). Is there a hierarchy of oppression in U.S. multicultural teacher education coursework? Action in Teacher Education, 33, 455-475.

Gorski, P., \& Swalwell, K. (2015). Equity literacy for all. Educational Leadership, 72(6), $34-40$.

Graves, K. (2007). Doing the public's business: Florida's purge of gay and lesbian teachers, 1959-1964. Educational Studies, 41(1), 7-32.

Grumet, M. (1988). Bitter milk: Women and teaching. Amherst, MA. University of Massachusetts Press.

Gutek, G. L. (1995). A history of the western educational experience. Long Grove, IL: Waveland Press, Inc.

Hall, G. S. (1908). Feminization in school and home. In W. H. Page \& A. W. Page (Eds.), World's Work Vol. XVI (pp. 10237-10244). New York, NY: Doubleday, Page \& Company.

Harbeck, K. M. (1992). Gay and lesbian educators: Past history/future prospects. In K. M. Harbeck (Ed.), Coming out of the classroom closet: Gay and lesbian students, teachers, and curricula (pp. 121-40). New York, NY: Harrington Park Press.

Hoffman, N. (2003). Woman's "true" profession: Voices from the history of teaching. Cambridge, MA: Harvard University Press.

Human Rights Campaign (2015). Maps of State Laws and Policies. Retrieved from http://www.hrc.org/state_maps

Jantz v. Muci 976 F.2d 623 (10th Cir. 1992).

Kavanaugh v. Hemet Unified School District, No. 99-04090, CA Dep't Indus. Relations (2000).

Kinsey, A., Pomeroy, W. B., \& Martin, C. E. (1948). Sexual behavior in the human male. Philadelphia, PA: W.B. Saunders Company. 
Knapp, D. (2013) Attitude changed after closed-door meeting, ousted gay principal says. KATU Web Site. Retrieved from http://www.katu.com/news/local//nterviewwith-principal-who-says-he-was-fired-for-being-gay-211322551.html

Kosciw, J. G., Greytak, E. A., Palmer, N. A., \& Boesen, M. J. (2014). The 2013 National School Climate Survey: The experiences of lesbian, gay, bisexual and transgender youth in our nation's schools. New York, NY: GLSEN.

Krolikowski v. St. Francis Preparatory School (New York, Queens County Supreme Court, Sept. 2013).

Kugle, S. S. al Haqq (2013). Living out Islam: Voices of gay, lesbian, and transgender Muslims. New York, NY: NYU Press.

Kull, R. M., Kosciw, J. G., \& Greytak, E. A. (2015). From statehouse to schoolhouse: Anti-bullying policy efforts in U.S. states and school districts. New York, NY: GLSEN.

Lambert, E. (March, 12, 2015). Girl told she can't give speech on LGBT rights; Seminole district reverses decision. WKMG Local 6. Retrieved from: http://www.clickorlando.com/news/girl-told-she-cant-give-speech-on-lgbt-rightsseminole-district-reverses-decision/31761484

Leaper, C., \& Bigler, R. S. (2004). Gendered language and sexist thought. Monographs of the Society for Research on Child Development, 69, 128-142.

Levin-Epstein, M. (2015). Navigating LGBT issues. Principal Leadership, 16, 32-36.

Lovell v. Comsewogue School District 214 F. Supp. 2d 319 (2002 New York).

Lugg, C. A. (2003). Sissies, faggots, lezzies, and dykes: Gender, sexual orientation and a new politics of education? Educational Administration Quarterly, 39, 95-134.

Mann, H. (1841). Fourth annual report. Boston, MA: Duton \& Wentworth.

McDermott, K. (May 22, 2012) Illinois conservatives defeat anti-bullying measure, citing gay 'agenda.' St. Louis Post-Dispatch Online. Retrieved from http://www.stltoday.com/news/local/illinois/illinois-conservatives-defeat-antibullying-measure-citing-gay-agenda/article_1310d016-a437-11e1-8d9e0019bb30f31a.html

McGovern, A. E. (2012). When schools refuse to say gay: The constitutionality of antiLGBTQ no-promo-homo public school policies in the United States. Cornel Journal of Law and Public Policy, 22, 465-490.

Mintz, S. (2004) Huck's raft, a history of American childhood. Cambridge, MA: The Belknap Press.

Monk, D. (2011). Challenging homophobic bullying in schools: The politics of progress. International Journal of Law in Context, 7, 181-207.

Morrison v. State Board of Education, 82 Cal. Rptr. 175, 461 P. $2 d 375$ (Cal. 1969)

Murray v. Oceanside Unified School District 95 Cal. Rptr. 2d 28 (2000). 
Nash, T. (December 29, 2010). Top 10: Teen suicides put spotlight on bullying. The Dallas Voice. Retrieved from: http://www.dallasvoice.com/teen-suicides-putspotlight-bullying-1058193.html

Lawrence v. Texas 539 U.S. 558 (2003).

Neumann, R. (2010). Social foundations and multicultural education course requirements in teacher preparation programs in the United States. Educational Foundations 10, 3-17.

Orfield, G. (2005). Post school desegregation 50 years after Brown: Misconceptions, lessons learned, and hopes for the future, Center for the Study of Ethics in Society, 15(3), 1-22.

Padgett, T. (2011). A teacher is back in class after anti-gay diatribe but did he really win? Time Magazine Online. Retrieved from http://content.time.com/time/nation/ article/0,8599,2091038,00.html

Paparo, S., \& Sweet, B. (2014). Negotiating sexual identity: The experiences of two gay and lesbian preservice music teachers. Bulletin for the Council of Research on Music Education, 199, 19-37.

People for the American Way. (2012). The right wing's anti-anti-bullying strategies. Washington, DC: Author. Retrieved from http://site.pfaw.org/pdf/ RRWIF_ Big_Bullies_Update.pdf

Pickering v. Board of Education, 391 U.S. 563 (1968).

Prettyman, S. (2007). Pressure points: Intersections of homophobia, heterosexism, and schooling. Educational Studies, 41, 3-6.

Richardson, J., \& Hatcher, B. (1983). The feminization of public school teaching 18701920. Work and Occupations, 10, 81-100.

Rowland v. Mad River Local School District, 470 U.S. 1009 (1985).

Rudoe, N. (2010). Lesbian teachers' identity, power and the public/private boundary. Sex Education, 10(1), 23-36.

Rury, J. (2004). Education and social change: Themes in the history of American schooling. New York, NY: Routledge.

Russell, S. T., Kostroski, O., McGuire, J. K., Laub, C., \& Manke, E. (2006). LGBT issues in the curriculum promotes school safety. San Francisco, CA: California Safe Schools Coalition.

Sapp, J. (2013). 'You're going to hell': When queer critical multicultural affirmation meets Christian homophobia. In P. Gorski, K. Zenkov, N. Osei-Kofi, \& J. Sapp (Eds.), Cultivating social justice teachers (pp. 184-203). Sterling, VA: Stylus.

Sausa, L. A. (2005). Translating research into practice: Trans youth recommendations for improving school systems. Journal of Gay and Lesbian Issues in Schools, 3, 15-28.

Shields, S. A. (2008). Gender: An intersectionality perspective. Sex Roles, 59, 301-311. 
Singh, A. A. (2013). Transgender youth of color and resilience: Negotiating oppression and finding support. Sex Roles, 68(11), 690-702.

Strober, M., \&. Gordon A. (1986). The feminization of public school teaching: A crosssectional analysis 1850-1880. Signs, 11, 212-235.

Sugg, R. S. (1978). Motherteacher: The feminization of American education. Charlottesville, VA: University Press of Virginia.

Tanis, C. (June 18, 2015). Gay teacher: Gerry Crane's story. Between the Lines. Retrieved from http://www.pridesource.com/article.html?article $=71990$

Tinker v. Des Moines Sch. Dist., 393 U.S. 503 (1969).

Tyack, D. (1974). The one best system. Cambridge, MA: Harvard University Press.

U.S. Department of Education, National Center for Education Statistics. (2015). Digest of Education Statistics, 2013 (NCES 2015-011).

Urban, W. J., \& Wagoner, J. L., (2013). American education. New York, NY: Routledge.

Waas, M., \& Rowland, C. (June 12, 2012) Mass. stalled antibullying guide under Romney objections to writing 'transgender,' 'bisexual.' The Boston Globe Online. Retrieved from http://www.bostonglobe.com/news/nation/2012/06/11/mittromney-administration-stifled-antibullying-guide-over-language-bisexualtransgender-youth/4GDs8p0YgnxObxuHUpPWaK/story.html

Waller, W. W. (1932). The sociology of teaching. New York, NY: Wiley.

Weaver v. Nebo School District, 29 F. Supp. 2d 1279 (D. Utah 1998).

Welter, B. (1966). The cult of true womanhood: 1820-1860. American Quarterly, 18(2), 151-174.

Woody, T. A. (1929). A history of women's education in the United States. New York, NY: Science Press.

Wright, T. E. (2010). LGBT educators perceptions of school climates: Administrators' attitudes and district policies can make significant contributions to creating safe environments for LGBT educators. Phi Delta Kappan, 91(8), 49-53.

\section{Appendix A \\ Selected LGBT Cases and Incidents}

Pickering v. Board of

Education (1968)

Illinois

Tinker v. Des Moines (1969)
A high school teacher wrote a letter to a newspaper criticizing the board of education funding actions. $\mathrm{He}$ was subsequently dismissed. Pickering sued and won claiming his First Amendment rights were violated.

Students were suspended for wearing armbands protesting U.S. involvement in the Vietnam War. 
lowa

The students sued and won on the basis that their First Amendment rights were violated.

Morrison v. State Board of

Mr. Morrison was reported to the superintendent as

Education (1969) being gay. His teaching qualifications were revoked

California due to "moral unfitness" stemming from limited non-criminal same-sex conduct

Gaylord v. Tacoma School

District (1975)
Washington

A student approached the vice-principal and said that he thought Mr. Gaylord he was gay. When confronted, Mr. Gaylord admitted that he was gay and he was subsequently dismissed for this reason. The court decided "it was a choice that was immoral and that public knowledge of this would damage his relationship with students and the community and that gay and lesbian teachers could not be role models." The dissent stated, however, that being gay did not preclude competence.

Ancanfora v. Board of

Education (1974)

Maryland

Mr. Ancafora was removed from classroom because, according to the superintendent, he didn't reveal that he was a member of a gay organization, that having a gay teacher does not provide a good role model for students, and because his case was so publicized that his return would be too controversial. He battled from 1971-1974 and although the courts agreed that he was denied due process and that his sexual orientation did not diminish his teaching performance, he was never reinstated.

Burton v. Cascade School District Union High School (1975)

Oregon
Peggy Burton, a non-tenured teacher, was dismissed "because of her immorality of being a practicing homosexual" pursuant to a state clause that read that teachers could be dismissed for "immorality." The 9th Circuit Court of Appeals upheld the decision to grant the teacher damages for wrongful dismissal but refused to reinstate her although there was no evidence that the teacher's sexual orientation had a negative impact on her job performance

A federal appeals court upheld an Ohio school system's decision to fire a guidance counselor, Ms. Rowland, after she told a secretary and several teachers that she was bisexual. They rejected Ms. Rowland's free speech issue and equal protection 
claim.

Bowers v. Hardwick (1986) Georgia
The U.S. Supreme Court upheld a Georgia sodomy law criminalizing private and consensual oral and anal sex when applied to gay men and lesbians. This was later overturned in Lawrence v. Texas (2003).

Jantz v. Muci (1992)

Kansas
Jantz was turned down for a teaching job in Kansas because the principal, Cleofas Muci, claimed Jantz had 'homosexual tendencies' although Jantz never said he was gay and, in addition, he was married with 2 children. The court ruled for the plaintiff based on the $14^{\text {th }}$ Amendment.
Gerry Crane and the Byron Center (Michigan, 1996)

Michigan
Byron City school music teacher Gerry Crane and his partner decided to have a commitment ceremony. When the news of the event spread in the community, parents demanded that he be fired. $\mathrm{He}$ was not fired but was investigated and monitored. After the school year ended he agreed to take a year's salary, health benefits and a letter of recommendation to leave quietly. In 1997, Gerry died of a massive heart attack, which is speculated to have been a result from the constant anxiety and stress endured. He was 33. (Tanis, 2015)

Glover claimed he was fired after having been seen at a party holding hands with another man. He claimed that he was discriminated against based on his gender, sexual orientation and the race of his partner. The court ruled that a teacher's credentials can be revoked for unprofessional conduct (California Education Code 13202) only if it can be demonstrated that it manifests in an unfitness to teach.

Weaver v. Nebo School District (1998)

Utah

Wendy Weaver lost her place as a volleyball coach after the school learned she was a lesbian. The court held that a school district could not prevent teachers from discussing their sexual orientation: if heterosexual teachers were allowed to do so, so were LGBT teachers. The court maintained that the school district violated Ms. Weaver's First and Fourteenth Amendments.

Citizens of Nebo School District v. Weaver (1997)
A group of parents tried (and failed) to get Ms. Weaver's teaching license revoked, claiming she 
Utah was breaking sodomy laws and that "an openly lesbian teacher was unfit to be a role model and otherwise participate as a full citizen." Unified School District (2000)

California
Murray v. Oceanside

Oceanside Unified School District award-winning biology teacher Ms. Murray went to court due to the years of harassment on the basis of her sexual orientation from her colleagues and having been denied a promotion. The court ruled in her favor based on California's nondiscrimination statute.

Kavanaugh v. Hemet Unified School District, (2000)

California

Lovell v. Comsewogue

School District (2002)

New York
Hemet Unified School District allowed parents to remove their children from Ms. Kavanaugh's classroom because she was a lesbian. The labor commissioner issued an order to stop acquiescing to these requests stating that it was discriminatory.
A lesbian teacher sued school officials for not addressing harassment she had faced from students because of her sexual orientation. The court ruled in her favor based on an equal protection claim.

Lawrence v. Texas (2003) US Supreme Court ruled that sodomy laws were Texas unconstitutional.

Krolikowski (2013)

New York
Veteran teacher Mark Krolikowski came out as transgender to his employers after one parent kept complaining about his 'feminine' appearance in 2011. He recently filed a lawsuit saying the school and its principal, Leonard Conway, broke the law with his termination. Mr. Krolikowski was branded "worse than gay" (Basu, 2013, ๆ 24).

\section{Author Contact}

Michele Kahn: kahnmm@uhcl.edu

University of Houston-Clear Lake, 2700 Bay Area Blvd., Houston, TX 77058, USA

Paul C. Gorski: gorski@edchange.org

George Mason University, 4400 University Drive, Fairfax, VA 22030, USA 